\title{
EDISTÄVÄ JA VIIHDYTTÄVÄ AIKUISKASVATUS
}

\author{
Aulis Alanen - Symposiumi Ja VAPAAN \\ SIVISTYSTYÖN TUTKIJATAPAAMINEN 16.-
} 17.8.2004 TAMPEREEN YLIOPISTOSSA

\section{KÄSITELTYJEN TEEMOJEN KIRJOA}

$\mathrm{E}$ lokuiseen Aulis Alanen -symposiumiin osallistunut joukko edusti vapaan sivistystyön kenttää monipuolisesti niin opetuksen, tutkimuksen kuin hallinnonkin alueilta. Joukossa oli myös meidän kaltaisia osallistujia, joiden tavoitteena lähinnä oli selkiyttää oman tutkimusalueensa kosketus- ja rajapintoja sekä suhdetta vapaaseen sivistystyöhön, sen sisältöihin, toimintamuotoihin ja toimijoihin. Omien tutkimusaluereviirien puolustaminen osoittautui jälleen kerran tarpeettomaksi, sillä niin olennaisia yksilöä ja yhteiskuntaa koskevia teemoja keskustelussa vilisi. Aiheet käsittelivät kasvatus-, koulutus- ja oppimiskäsitteiden määrittelyä sekä aikuiskasvatuksen ja -kasvattajien suhdetta historiaan, nykyisyyteen ja tulevaisuuteen. Puheenvuoromme rakentuu niiden välittömien tunnelmien ja tulkintojen varaan, joita meille päivien aikana heräsi.

Symposiumin teemat käsittelivät laajasti vapaan sivistystyön kenttää Aulis Alasen tuotantoon peilattuna. Teemoissa edettiin Alasen määrittelyn mukaisesti aina myötäilevän sivistyspolitiikan ajasta markkinaperustaiseen aikuiskasvatuksen aikaan. Opintokerhotyötä käsittelevän Alasen väitöskirjan kysymyksenasettelut jäsensivät monin tavoin tämän päivän kysymyksiä opintojen edistävyydestä ja/tai viihteellisyydestä sekä niiden yhdistymisen rajoituksia ja mahdollisuuksia. Niin ikään elinikäistä oppimista, kansaa ja sivistystä käsittelevät Alasen tekstit keskusteluttivat osallistujia ajankohtaisista kansalaisuuden ja kansalaisyhteiskunnan, järjestösidonnaisuuden, aikuiskasvattajien pätevyyden ja vapaan sivistystyön tulosten arvioinnin teemoista. Monissa puheenvuoroissa perättiin aikuiskasvatuksellisten käsitteiden nykyistä huolellisempaa ja kohdallisempaa määrittämistä ja käyttöä, jota myös Alanen omassa tuotannossaan tavoit-

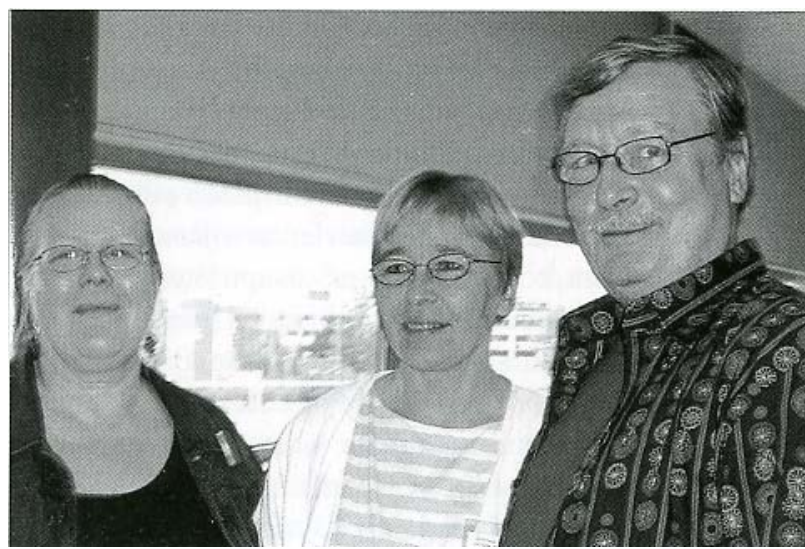

VSOP-projektisihteeri Leena Saloheimo sekä seminaarissa esitelmöineet professori Leena Koski ja professori Jukka Tuomisto taukokeskustelussa

teli. Alasen tekstit ja työskentely hänen kanssaan oli ollut selvästi osalle osallistujista hyvin merkityksellistä mm. henkilökohtaisen kasvatuksellisen ymmärryksen muotoutumisen näkökulmasta. Puhujien henkilökohtaiset kokemukset toivat väriä ja elävyyttä puheenvuoroihin. Alasen merkitys aikuiskasvatuksen tieteelliselle kehitykselle sai esityksissä näkyvän ja perustellun osan.

Käsitteiden määrittelyn lähtökohdista tutkijat nostivat esille erilaisia vapaan sivistystyön kentän ongelmia. Samoja huolenaiheita, joskin hieman eri sanoin ja tavoin, esittivät opisto- ja järjestökentän toimijat. Huolta kannettiin mm. kansalais- ja kansanopistojen tulevaisuudesta. Ne kun ovat, monien muiden tahojen tapaan, kohdanneet 'kaiken muuttumisen' ja ‘jatkuvassa muutoksen tilassa olemisen' haasteet. Eri opistojen ja järjestöjen edustajien puheenvuoroissa heijastui huoli mm. toimintojen taloudellisesta ohjausjärjestelmästä sekä sivistyksellisestä ai- 
neksesta. Näiden lisäksi sosiaalisten vuorovaikutusmuotojen ja arkielämän toimintojen muuttuminen olivat esimerkkejä niistä haasteista, joita vapaan sivistystyön kentällä on jouduttu viime aikoina pohtimaan. Opistojen kilpailuasetelma sekä alueellisten tarpeiden ja toisaalta EU-tason tavoitteiden yhteensovittamisen jännite on opistojen arkipäivää. Osan niistä tehtävistä, joita vapaa kansansivistys on historiansa aikana Suomessa hoitanut, todettiin siirtyneen sosiaalija työvoimapolitiikan piiriin. EU-kansalaisuuden myötä keskustelu poikkesi hetkeksi myös kansainvälisille kentille nostaen esille kansainvälistymisen haasteet. Vertailua kansainvälisiin tutkimuksiin tai kansainväliseen tilanteeseen tehtiin globalisaatiopohdintaa lukuun ottamatta vähäisessä määrin. Kritiikki ja haasteet kulminoituivat uusliberalistiseen politiikkaan ja sen aiheuttamiin muutoksiin mm. vallitsevien arvojen osalta.

Entä kohtasivatko eri osapuolten esittämät huolenaiheet? Erään osallistujan puolileikillinen kommentti siitä, että: 'Tieteen tekijät nyt sitten arvioivat, olemmeko myyneet itsemme kapitalismille’, voitaisiin tulkita viestittävän eri tahojen jonkintasoisesta kohtaamattomuudesta. Klassinen kysymys teorian ja käytännön välisestä suhteesta sekä kysymys siitä, lisääkö tutkimustieto vain käytännössä toimivien taakkaa nousivat myös esille. Nämä haasteet herättävät pohtimaan vapaan sivistystyön yhteisöllisyyden tilaa; kenen kanssa yhteistyötä tehdään ja halutaan tehdä, niin kansallisella kuin ylikansallisellakin tasolla.

\section{MENNYT - NYKYISYYS - TULEVAISUUS}

Seminaarin keskustelujen tarkastelu nostaa esille kasvatuksellisen peruskysymyksen: miten suhtaudumme menneeseen sekä mitkä ovat menneen, nykyisyyden ja tulevaisuuden väliset suhteet. Aikuiskasvatuksen ja kasvatustieteen alamäärittelyissä ja kehittämissuunnissa tältä kysymykseltä ei voi välttyä. Yhdessä puheenvuoroista kertosäkeen omaisesti toistettiin: "Ennen oli ennen ja nyt on nyt.” Luentokeskusteluissa mielestämme painottuivat juuri menneen ja nykyisyyden välisen suhteen tarkastelu. Puheenvuoroissa kuitenkin todettiin, että jonkin on vapaan sivistystyön kentällä muututtava tai monet toiminnot esim. järjestöpuolella näivettyvät, joten merkkejä tulevaisuuteen suuntautumisesta oli myös il- massa. Aikaperspektiivien kohtaamisessa huomioitava tekijä on eri toimijoiden mahdollisuudet tarkastella aikaa. Voivatko tutkijat helpommin liikkua menneisyys-nykyisyys-tulevaisuus -akselilla muun kenttäväen joutuessa keskittymään ennemminkin nykyisyyden ja tulevaisuuden väliseen suhteeseen? Tämänkaltaisessa kahden päivän tapaamisessa tulevaisuutta ei ehditty kovinkaan syvällisesti jäsentämään. Kuva tulevaisuudesta välittyi meille haasteellisena ja pirstaleisena, mikä monien ajan teoreetikkojen mukaan kertoo osuvasti ajasta jota tällä hetkellä elämme.

Millaisin askelin vapaan sivistystyön kentällä symposiumin pohjalta lähitulevaisuudessa edetään? Keskustelussa oli tunnistettavissa uskoa uudenlaisiin sosiaalisen toiminnan muotoihin ja aktiiviseen kansalaisuuteen. Paikallinen toiminta ja ihmisten kohtaaminen arjessa nähtiin avaintekijöinä. Teemaryhmissä käsitellyt tutkimus- ja case -esimerkit olivat myös osoituksia innostuneesta toimintojen kehittämisestä ja tulevaisuusorientaatiosta. Moninaisten kehittämishankkeiden ja projektien ohella yhtenä tulevaisuuden toimintamuotona esiteltiin käynnistyvä Vapaan Sivistystyön -tutkimushanke, joka kohdistuu vapaan sivistystyön arvioinnin ja aktiivisen kansalaisuuden teemoihin. Tutkijoiden ja käytännön toimijoiden kohtaamispaikaksi suunnitellut foorumit sekä oppikirjahanke esiteltiin myös lähitulevaisuuden toiminta- ja yhteistyömuotoina.

Jäimme ihmettelemään, missä olivat tulevien toimijoiden esim. aikuiskasvatusta päätoimisesti opiskelevien äänet. Olisivatko suunnitellut keskustelufoorumit mahdollisesti niitä paikkoja, joissa olisi aikaa pohtia eri tahojen yhteisiä ja toisaalta eriytyviä 'huolia' ja joihin osallistuisi myös uusi sukupolvi? Vapaan sivistystyön perusajatuksiin kun kuitenkin kuuluu yhteisöllisyyden rakentaminen ja seuraavasta sukupolvesta välittäminen. Päivien aikana kuultujen puheenvuorojen moniäänisyys tiivistyy mielestämme kysymykseen, miten mennyt saadaan dialogiin nykyisyyden ja tulevaisuuden kanssa.

\section{Virve Kallioniemi ja Kati Tikkamäki}

Seminaarin ohjelma osoitteessa http://www.vsy.fi 